\title{
DAMPAK DUKUNGAN SOSIAL ORANG TUA TERHADAP PROKRASTINASI AKADEMIS SISWA XI ADMINISTRASI PERKANTORAN (Studi Kasus di SMK Tunas Harapan)
}

\author{
Leniawati $^{1}$ \\ Moch Dimyati, M.Pd ${ }^{2}$ \\ Happy Karlina Marjo, M.Pd, Kons ${ }^{3}$
}

\begin{abstract}
Abstrak
Penelitian ini bertujuan untuk mengungkap berbagai fakta tentang dampak dukungan sosial orang tua terhadap prokrastinasi akademik yang dilakukan oleh siswa SMK Tunas Harapan. Penelitian ini menggunakan pendekatan kualitatif dengan metode studi kasus yang bermaksud untuk memperoleh pemahaman yang utuh dan menyeluruh mengenai Dampak Dukungan Sosial Orangtua Terhadap Prokrastinasi siswa SMK Tunas Harapan khususnya kelas XI. Adapun responden yang diteliti dalam penelitian ini adalah siswa SMK Tunas Harapan kelas XI AP (Administrasi Perkantoran) yang beinisial FR dan DA. FR dan DA adalah sebagian siswa yang melakukan prokrastinasi yang tinggi dan belum mendapatkan dukungan sosial orang tua secara maksimal dan tepat. Berdasarkan hasil penelitian diketahui FR mendapatkan aspek reassurance of worth (penghargaan atau pengakuan) dan opportunity for naturance (kemungkinan dibantu) namun karena kurangnya aspek yang lain seperti guidance (bimbingan) sehingga FR kurang kontrol dalam perilakunya sehari-hari dan menyebabkan FR tetap memiliki prokrastinasi yang tinggi. Pada subyek DA hanya mendapatkan dukungan sosial guidance (bimbingan) namun karena latar belakang orang tua DA yang hanya tamatan SD sehingga bimbingan yang diberikan tidak maksimal dan aspek lain sebagai penunjang untuk memotivasi DA belum diberikan sehingga DA tetap mengalami prokrastinasi Akademis.
\end{abstract}

Kata Kunci: Prokrastinasi Akademis, Dukungan Sosial Orang Tua

\section{Pendahuluan}

Siswa SMK (Sekolah Menengah Kejuruan) ialah individu yang berada pada masa remaja. Siswa SMK berada pada masa yang cukup penting untuk diperhatikan karena individu banyak mengalami perubahan yang terjadi pada dirinya seperti dalam beberapa aspek yakni fisik, kognitif, emosi serta hubungan sosialnya.
Hurlock menjelaskan karakteristik yang dimiliki oleh siswa, dimana siswa yang memasuki masa remaja memiliki karakteristik dari segi fisik dan mental. Fisik sudah memiliki pertumbuhan dan kematangan yang sempurna dan lengkap. Seperti tulang-tulang yang sudah kuat, membesar dan menyerupai orang dewasa pada umumnya. Dari segi mental sudah mulai menemukan jati dirinya dan sudah menjadi individu yang lebih mandiri. Hal ini dimu-

\footnotetext{
1 Mahasiswa Jurusan Bimbingan dan Konseling FIP UNJ, leniada_disini@yahoo.co.id

2 Dosen Bimbingan dan Konseling FIP UNJ, moch_dimayati@yahoo.com

3 Dosen Bimbingan dan Konseling FIP UNJ, happy.hanum2007@gmail.com
} 
lai melepaskan ketergantungan terhadap orangorang dewasa disekitarnya seperti keluarga. Oleh karena itu individu tersebut cenderung berkelompok dan memilih lingkungan untuk bersosialisasi menurut usianya.

Konflik yang muncul dikhawatirkan berpengaruh pada prestasi akademik siswa. Oleh karena itu, siswa perlu mendapatkan dukungan atau teman dalam menghadapi konfliknya. Tidak dapat dipungkiri, orang tua memilki peran yang berpotensi paling besar sebagai teman remaja (siswa) dalam menghadapi konflik dalam dirinya maupun dengan orang lain.

Selain itu banyaknya orang tua yang tidak memiliki pengetahuan tentang bagaimana membimbing remaja dan memberikan dukungannya secara tepat sangat di sayangkan memang. Orang tua yang demikian biasanya juga akan memberikan dukungan sosial kepada anaknya dengan cara yang tidak tepat. Hal ini menyebabkan para siswa remaja banyak menghadapi masalah-masalahnya sendiri dan cenderung permasalahan tersebut tidak dapat terselesaikan dengan baik. Pada akhirnya muncul gejala penundaan pekerjaan tugas akademik.

Di SMK Tunas Harapan berdasarkan hasil pengamatan peneliti kejadian ini di sebabkan salah satu faktornya yaitu dengan tidak adanya dukungan sosial orang tua yang diberikan kepada mereka. Sebagai contoh, berdasarkan hasil wawancara ada siswa yang merasa kurang diperhatikan ketika berada di rumah, siswa juga merasa fasilitas yang diberikan oleh orang tua untuk menunjang mereka belajar kurang, dan tidak ada pemberian kurangnya motivasi yang diberikan orang tua.

Berdasarkan hal tersebut peneliti menafsirkan orang tua siswa tersebut cenderung tak acuh dan lebih sibuk dengan urusannya sendiri. Selain itu, orang tua jarang yang menanyakan kabar dan kegiatan anaknya saat di Sekolah. Sehingga orang tuapun kurang mengetahui perkembangan anak-anaknya di Sekolah.

Berdasarkan identifikasi masalah diatas, maka penelitian ini dirumuskan pada: Dampak Dukungan Sosial Orangtua Terhadap Prokrastinasi Akademik Siswa SMK Tunas Harapan, yakni pada siswa XI AP yang bernama FR dan DA.

\section{Kajian Teori \\ Dukungan Sosial Orang Tua}

Dukungan orang tua merupakan bagian dari dukungan sosial. Oleh karena itu, sebelum membahas pengertian dukungan sosial orang tua, maka terlebih dahulu peneliti menjelaskan mengenai dukungan sosial.

Gottlieb menyatakan bahwa dukungan sosial terdiri dari informasi atau nasehat verbal ataupun non verbal, bantuan nyata, atau tindakan yang diberikan oleh keakraban sosial atau didapat karena kehadiran mereka mempunyai manfaat atau efek perilaku bagi pihak pertama. Sejalan dengan pernyataan Gottlieb, Cochen dan Wills mendefinisikan dukungan sosial sebagai bantuan atau pertolongan yang diterima oleh seseorang dari interaksinya dengan orang lain. Dukungan yang diperoleh siswa SMK Tunas Harapan misalnya saja, dengan fasilitas yang diberikan oleh orang tua atau pihak sekolah guna menunjang dalam proses akademik siswa tersebut.

Weiss mengembangkan "Social Provisions Scale" untuk mengukur ketersediaan dukungan sosial yang diperoleh dari hubungan individu dengan orang lain. Terdapat enam komponen atau aspek didalamnya, yaitu :

a. Attachement (kasih sayang/ kelekatan) merupakan perasaan akan kedekatan emosional dan rasa aman. Anak memiliki kedekatan secara emosional dengan orang tua, merasa disayangi dan merasakan aman ketika berada dekat dengan orang tua

b. Social integration (integrasi sosial) merupakan perasaan menjadi bagian dari keluarga dan tempat saling berbagi minat dan aktifitas dengan keluarga

c. Reassurance of worth (penghargaaan/pengakuan) meliputi pengakuan akan kompetensi dan kemampuan anak. Anak merasa diakui akan kemampuan yang dimiliki

d. Reliable alliance (ikatan/hubungan yang dapat diandalkan) meliputi kepastian atau jaminan bahwa anak dapat mengharapkan orangtua untuk membantu dalam semua keadaan baik fisik atau materi

e. Guidance (bimbingan) merupakan nasehat dan pemberian informasi oleh orangtua kepada anak

f. Opportunity for naturance (kemungkinan diban- 
tu) merupakan perasaan anak akan tanggung jawab orangtua terhadap apa yang dibutuhkan anak, baik dari segi materi atau fasilitas sehingga semua kebutuhan anak tercukupi

\section{Prokrastinasi Akademis}

Prokrastinasi berasal dari gabungan kata pro dan crastinate yang dalam bahasa latin disebut crastinus. Pro berarti memajukan, melanjutkan atau lebih menyukai dan crastinate berarti sampai besok. Jika digabungkan dengan kata ini berarti memajukan, melanjutkan atau lebih menyukai melakukan aktivitas dihari kemudian. Istilah ini pertama kali digunakan secara ilmiah untuk menunjukan pada suatu kecenderungan menunda-nunda penyelesain tugas atau pekerjaan.

Ferrari dkk, mengatakan bahwa sebagai suatu perilaku penundaan, prokrastinasi akademis memiliki ciri-ciri, yaitu:

a. Penundaan untuk memulai maupun menyelesaikan kerja tugas yang dihadapi

b. Keterlambatan dalam mengerjakan tugas

c. Kesenjangan waktu antara rencana dan kinerja aktual

d. Melakukan aktivitas lain yang lebih menyenangkan dari pada melakukan tugas yang harus dikerjakan

\section{Metode Penelitian}

Penelitian ini dilaksanakan di SMK Tunas Harapan. Waktu penelitian ini dilakukan pada bulan November 2013 sampai Juni 2014. Penelitian ini menggunakan pendekatan kualitatif dengan metode studi kasus yang bermaksud untuk memperoleh pemahaman yang utuh dan menyeluruh mengenai Pengaruh Dukungan Sosial Orangtua Terhadap Prokrastinasi siswa SMK Tunas Harapan khususnya kelas XI AP.

Penelitian ini menggunakan pendekatan kualitatatif yaitu penelitian yang bermaksud untuk memahami fenomena tentang apa yang dialami oleh subjek penelitian misalnya perilaku, persepsi, motivasi, dan tindakan dengan cara holistik atau menyeluruh dan cara deskripsi dalam bentuk kata-kata dan bahasa. . Deskripsi yang dimaksud adalah bentuk kata-kata dan bahasa pada konteks khusus alamiah dan dengan memanfaatkan berbagai metode alamiah.
Selain itu, pendekatan kualitatif digunakan dalam penelitian ini karena penelitian kualitatif ditujukan untuk: a) memahami isu-isu rinci tentang situasi dan kenyataan yang dihadapi seseorang; $b$ ) isu-isu yang sensitif; c) meneliti hal-hal yang berkaitan dengan latar belakang subjek penelitian (responden); d) memperoleh hasil penelitian yang lebih mendalam.

\section{Hasil dan Pembahasan}

Berdasarkan hasil penelitian diketahui FR mendapatkan aspek reassurance of worth (penghargaan atau pengakuan) ini dilihat dari keseharian FR, ketika FR mencapai prestasi orang tua FR selalu memberikan hadiah. FR juga mendapatkan dukungan terhadap kemampuan yang dimilikinya dengan diberika fasilitas tambahan yang mendukung kemampuannya dalam bermain bola. Pada aspek opportunity for naturance (kemungkinan dibantu) FR mendapatkan fasilitas sesuai yang dia butuhkan seperti mendapatkan ruang belajar yang nyaman dan ruang pribadi untuk berekspresi. Namun karena kurangnya aspek yang lain seperti Attachement (kasih sayang/kelekatan), Social Integration (integrasi sosial), reliable alliance (ikatan atau hubungan dapat diandalkan) dan guidance (bimbingan), sehingga FR kurang diberikan arahan dan bimbingan dalam kesehariannya khususnya masalah sekolah, FR ketika di rumahpun kurang kontrol dalam perilakunya sehari-hari dan menyebabkan FR tetap memiliki prokrastinasi yang tinggi.

DA hanya mendapatkan aspek guidance (bimbingan) ini terlihatjika ia melakukan kesalahan orang tuanya selalu memberikan arahan jika perilakunya atau dia mengikuti kegiatan yang kurang baik, namun untuk membimbing dalam hal belajar orang tuanya memang kurang bisa memahami pelajaran DA, dikarenakan latar belakang pendidikan orang tua DA yang hanya sampai Sekolah Dasar (SD). Selain itu orang tua DA sibuk mencari nafkah karena DA memang berasal dari keluarga yang sederhana. Dengan adanya aspek dukungan sosial yang rendah dan kurang maksimal menyebabkan DA melakukan prokrastinasi akademis yang tinggi.

Hasil dari penelitian menunjukan jika dukungan sosial orang tua yang didapat anak hanya sedikit dan kurang tepat maka anak akan memiliki prokrastinasi yang tinggi, begitupun sebaliknya jika dukungan so- 
sial orang tua yang diberikan secara tepat dan sesuai dengan apa yang anak harapkan maka prokrastinasi akan menurun bahkan tidak ada.

\section{Kesimpulan dan Saran Kesimpulan}

Secara keseluruhan dampak dukungan sosial orang tua terhadap prokrastinasi akademis yang dilakukan oleh FR dan DA berbeda. Berdasarkan hasil penelitian diketahui FR mendapatkan aspek reassurance of worth (penghargaan atau pengakuan) dan opportunity for naturance (kemungkinan dibantu). Pada subyek DA hanya mendapatkan dukungan sosial guidance (bimbingan).

\section{Saran}

\section{a. Saran untuk Guru BK}

Guru BK di SMK Tunas Harapan sebaiknya melakukan arahan untuk siswa agar tidak melakukan prokrastinasi, dengan melakukan bimbingan dan konseling kelompok atau individu kepada siswa yang memiliki masalah serupa, khususnya dukungan sosial orang tua sehingga prokrastinasi yang ada di sekolah tersebut bisa berkurang. Kemudian memberikan arahan kepada orang tua tentang bagaimana cara memberikan dukungan sosial orang tua secara tepat kepada siswa dengan menjalin hubungan komunikasi yang lebih baik dan dekat dengan anak.

\section{b. Saran untuk orang Tua FR dan DA}

Untuk orang tua FR diharapkan agar lebih memberikan waktu memantau perkembangan dan perilaku FR di rumah sehingga orang tua dapat mengetahui perkembangan sekolah FR dengan baik dan dapat mengarahkan FR untuk tidak melakukan prokrastinasi akademis. Untuk orang tua DA, diharapkan agar lebih memberikan motivasi, semangat dan lebih terbuka dalam mengekpresikan bentuk perhatian secara emosional kepada DA, sehingga DA memiliki motivasi dan lebih berfikir positif untuk tidak melakukan prokrastinasi.

\section{c. Saran untuk Orang Tua}

Bagi orang tua sebaiknya menanamkan sifat positif dalam diri anak, lebih menjalin hubungan komunikasi yang lebih baik dan terbuka antara anak dan orang tua. Dengan memberikan dukungan dan motivasi bahwa anak mampu dan memiliki potensi yang pantas dibanggakan dalam dirinya, sehingga agar anak mangurangi perilaku prokrastinasi akademik.

\section{d. Untuk siswa}

FR diharapkan lebih terbuka kepada orang tua dan mencoba berdiskusi dengan orang tua apa yang FR inginkan dan belum FR dapatkan. FR jangan menghindar dan sebaiknya lebih sering di dalam rumah sehingga waktu bersama menjadi lebih banyak dan hubungan komunikasi yang terjalin menjadi lebih baik.

\section{e. Untuk siswa}

Siswa diharapkan lebih terbuka terhadap orang tua apa yang dirasakan dan diperlukannya dari orang tua. Siswa diharapkan dapat menjalin hubungan komunikasi yang baik dan terbuka dengan orang tua, sehingga ketika mengalami kesulitan membutuhkan bantuan dapat tersampaikan dengan baik.

\section{Daftar Pustaka}

A.H.C. Chu \&J.N Choi. Rethinking procrastination: positive effects of "achive" procrastination behavior on attitudes and performance, (journal of Social Psychology 2005)p., 245-264

Ahmad fahrur, Pengaruh Perhatian Orang tua terhadap Prestasi Belajar Anak, p. 12012 (http://ahmad-fahrur. blogspot.com/2012/04/pengaruh-perhatian-orangtua-terhadap.html)

A.M Kring, dkk, Abormal Psychology Tenth Edition (Columbia: John Wiley and Sons, ic, 2007)p.,31

Bishop, dalam S.E. Taylor. Health Psychology Fifth Edition (New York: McGraw Hill)p., 93

Brown \& Holzman, dalam Hayyinah. Religiutas dan Prokrastinasi Akademik Mahasiswa. (psikologika, no.17 tahun IX, 2004)p., 32

B.R. Sarason. 1987. Interralations of social support measures: Theoritical and practical implication. Journal of personality and social psychology, p., 813-832

C.A. Sanderson. Health Psychology (New Jersey: John Wiley-Sonc, Inc)p.,43

C.E. Cutrona. Objective determinants of perceived social support. Journal of Personality and Social Psychology, p., 50

C.L. Cooper, dkk. Organizational Stress: Areview and Critique of Theory, Research, and Applications. p,.62 